\title{
Modeling of the Coastal Zone Relief and Granulometric Composition Changes of Sediments in the Region of the Bogaily Lake Bay-Bar (the Western Crimea) during Storm
}

\author{
K. I. Gurov*, V. F. Udovik, V. V. Fomin \\ Marine Hydrophysical Institute of RAS, Sevastopol, Russian Federation \\ *gurovki@gmail.com
}

\begin{abstract}
Introduction. A series of numerical experiments was carried out to study the mechanism of storm deformations of the coastal zone relief and the redistribution of different sediment fractions after the parameters of the wind waves directed almost normally to the coastline, are changed.

Data and methods. The lithodynamic processes taking place at the Western Crimea coastal zone in the region of the Lake Bogaily bay-bar were investigated using the XBeach mathematical model. The in-situ data on the bottom relief and the sediments granulometric composition obtained during monitoring observations in the Western Crimea coastal zone performed by the Marine Hydrophysical Institute of RAS was used as the model input parameters. The granulometric composition was preset as a mixture of three components distributed along the profile of the underwater coastal slope; at that the ratios of volume concentrations were different.

Results. It is shown that influence of the storm waves results in intensive beach erosion, strong alteration of the profile of the underwater coastal slope upper part and formation of an accumulative body. Main changes of the initial profile and redistribution of the sediment fractions are observed during the first 3-6 hours and depend on the wave period. The rate of the water edge retreat and the values of the coastal zone relief deformation were quantitatively assessed for various time periods of the wave action. Position of the marine boundary of the site within which significant motion of sediments and their accumulation during a storm took place was calculated.

Discussion and conclusion. Possibility of the bay-bar crest erosion is analyzed for the wind wave' different periods. It is shown that the volume concentrations of different components of the mixture change mainly after the fine fractions are rapidly removed to the seaward part of the bottom profile and the coarser fractions are redistributed in the upper part of the underwater coastal slope. The obtained results provide a possibility of indirect determining the conditions for blocking the alongshore sediments transport in case of building a hydraulic structure.
\end{abstract}

Keywords: coastal zone, Western Crimea, model XBeach, bottom sediments, relief storm deformation, granulometric composition.

Acknowledgements: the investigation is carried out within the framework of the state task on the theme No. 0827-2018-0004 "Complex interdisciplinary investigations of the oceanologic processes conditioning functioning and evolution of the Black and Azov seas' ecosystems of the coastal zones" (code "Coastal investigations") and at the RFBR partial support within the framework of the research project No. 18-35-00230.

For citation: Gurov, K.I., Udovik, V.F. and Fomin, V.V., 2019. Modeling of the Coastal Zone Relief and Granulometric Composition Changes of Sediments in the Region of the Bogaily Lake Bay-Bar (the Western Crimea) during Storm. Physical Oceanography, [e-journal] 26(2), pp. 170-180. doi:10.22449/1573-160X-2019-2-170-180

DOI: $10.22449 / 1573-160 X-2019-2-170-180$

(C) 2019, K. I. Gurov, V. F. Udovik, V. V. Fomin

(C) 2019, Physical Oceanography 


\section{Introduction}

Storm and seasonal changes of water edge position and bottom relief deformation are under-studied, which creates considerable difficulties in planning the various types of measures for the preservation and sustainable development of coastal areas. Inaccuracies in the estimates of these values often lead to the destruction of coastal infrastructure, residential buildings, coast protection structures and other hydrotechnical constructions. This greatly reduces the investment attractiveness of the coast.

The study of regional peculiarities of coastal zone relief re-shaping and the changes in the size composition of coastal-marine sediments on the Western Crimea coastal areas is particularly relevant due to the fact that the rate of the recreational potential development of this region has significantly increased.

The study of processes occurring at the land - sea boundary includes a complex of field observations, as well as the use of a wide range of mathematical models and calculation methods for forecasting the coastal development on various spatial and temporal scales [1-8].

In most studies, when modeling storm deformations of the coastal zone relief, sediment size values averaged over the entire computational domain $[9,10]$ are used. However, it is the grain size composition of bottom sediments that largely determines the characteristics of their movement under effect of waves and currents. The magnitude of beach profile deformations and the underwater coastal slope (UCS), which can persist for quite long time periods, are also closely related to the redistribution of various sediment fractions in the coastal zone during a storm.

The objective of this work is to study the local features of storm changes in the coastal zone profile and the redistribution of different sediment fractions on the coastal area of the region of the Bogaily Lake bay-bar (Western Crimea).

Previously, the works in this direction were carried out by the authors in respect of the Western Crimea coastal areas near Nikolaevka village [11] and the northern sector of the Lake Sasyk bay-bar [12].

Characteristic of the research area. The bay-bar of the Lake Bogaily is located in the northern sector of the Western Crimea coast abrasion section, stretching from Sevastopol to the southern boundary of the Lake Kizil-Yar [13]. The bay-bar length is about $1300 \mathrm{~m}$; the width is $55-60 \mathrm{~m}$; the height of the ridge above the mean sea level is from 2 to $2.5 \mathrm{~m}$. The relief of the beach and the underwater slope is rather homogeneous in the marine part. The isobaths are located almost parallel to the coastline. The width of the zone of the most active beach material wave processing ranges from 35 to $40 \mathrm{~m}$ and is clearly distinguished along the vegetation cover boundary. The surface of the ridge is complicated by residual relief depressions by $40-60 \mathrm{~cm}$ in places of seawater overflow through the top of the coastal bar during severe storms, accompanied by surge phenomena.

From the north and the south, the aboriginal coast sections, which are represented by actively collapsing cliffs of 10-12 $\mathrm{m}$ high, are adjacent to the bay bar. The leaning beaches of an incomplete profile existing here are up to 12-15 m wide, which is clearly not enough to protect the cliffs from wave abrasion. As a result, the cliffs and the coastline actively retreat in this area. Based on PHYSICAL OCEANOGRAPHY VOL. 26 ISS. 2 (2019) 
the data of Marine Hydrophysical Institute of Russian Academy of Sciences (MHI RAS) monitoring studies and the results obtained in [14, p. 44; 15], the values of $0.5-1 \mathrm{~m} /$ year are taken as the most reliable estimates of the coast retreat average rate in the area of the Lake Bogaily.

Cliffs are composed mainly of brown clay and contain an insignificant amount (from 2 to 16\%) of sand and larger fractions that can feed local beaches during the destruction of coastal cliffs $[13,16]$. Insufficient material inflow from the local sources leads to the fact that the main supply of accumulative relief forms in this coastal zone section occurs as a result of alongshore movement of sediments by the mean flow directed from the south to the north. From the point of view of the mean flow formation theory, which is the sum of single storm movements and detrital material migrations over a long period of time, this section of the coast can be attributed to the sediment transit zone within the lithodynamic system of the Kalamita Bay [13, 17-19]. Thus, the main changes in the coastal zone in this section occur mainly under effect of storm waves, having a direction close to the normal with respect to the coastline.

The results of grain size analysis showed that the main changes in the size composition of sediments are observed in the near-edge zone of the beach and in the UCS upper part of the coastal zone limited by $1.0-1.5 \mathrm{~m}$ isobaths. In a narrow strip located directly near the water edge, coarse and medium-grained sand with an admixture of fine-grained gravel prevails. With the depth increase, the proportion of coarse-grained material reduces and below $2.5 \mathrm{~m}$ it is completely absent. In the depth range from 2.0-2.5 to $4 \mathrm{~m}$, the aleurite-pelitic mixture with minor inclusions of fine-grained sand prevails in the samples *. The analysis of the values of the wind wave main parameters is based on the results presented in [20-22].

In [21], it was shown that in the Kalamita Bay water area the average height of storm waves reach $2 \mathrm{~m}$ or more at the south-western and western winds, which are especially dangerous for the region under study. According to the results obtained in [20] for the southwestern and western wind directions, the values of the mean wave period vary from $6 \mathrm{~s}$ at $5-10 \mathrm{~m} / \mathrm{s}$ wind velocity to $7-8 \mathrm{~s}$ at $15-20 \mathrm{~m} / \mathrm{s}$ wind velocity. For the storm western wind $(>20 \mathrm{~m} / \mathrm{s})$, the value of period reaches $9 \mathrm{~s}$ and more. In [22], it was shown that once every 10 years the waves with $8-9$ s period and once every 50-100 years the waves with $10 \mathrm{~s}$ period are observed in the Kalamita Bay.

Mathematical model and the input data. Storm deformations of the coastal zone profile and redistribution of various fractions of coastal-marine sediments were studied using the complex numerical model XBeach [23]. The origin of coordinates was located in the seaward part of the computational domain, $x$ axis was directed to the coast and $y$ axis was directed along the coastline. Considering the uniformity of the relief and sediment distribution in the alongshore direction, the $1 D$ version of the model was implemented.

\footnotetext{
* Gurov, K.I., Fomin,V.V. and Udovik, V.F., 2017. [Modeling of Storm Changes in the Bottom Relief and Granulometric Composition of Bottom Sediments in the Coastal Zone of the Crimean Peninsula]. In: MHI, 2017. Morya Rossii: Nauka, Bezopasnost', Resursy: Tezisy dokladov nauchnoy konferentsii (Sevastopol, 3-7 Oktyabrya 2017) [The Seas of Russia: Science, Safety, Resources: Abstracts of scientific conference papers (Sevastopol, 3-7 October 2017)]. Sevastopol, FSBSI MHI, p. 138 (in Russian).
} 
When carrying out numerical experiments, the data on the relief and granulometric composition of sediments, obtained during the monitoring observations carried out by MHI RAS, were used. The total profile length is $530 \mathrm{~m}$. At the initial moment of time, the first $493 \mathrm{~m}$ of the initial profile correspond to the UCS, and the remaining $37 \mathrm{~m}$ - to the beach and parts of the upper site on the Bogaily Lake bay-bar ridge (Fig. 1, a). The computational grid step is $1 \mathrm{~m}$. The calculations were carried out for a storm period of $48 \mathrm{~h}$.

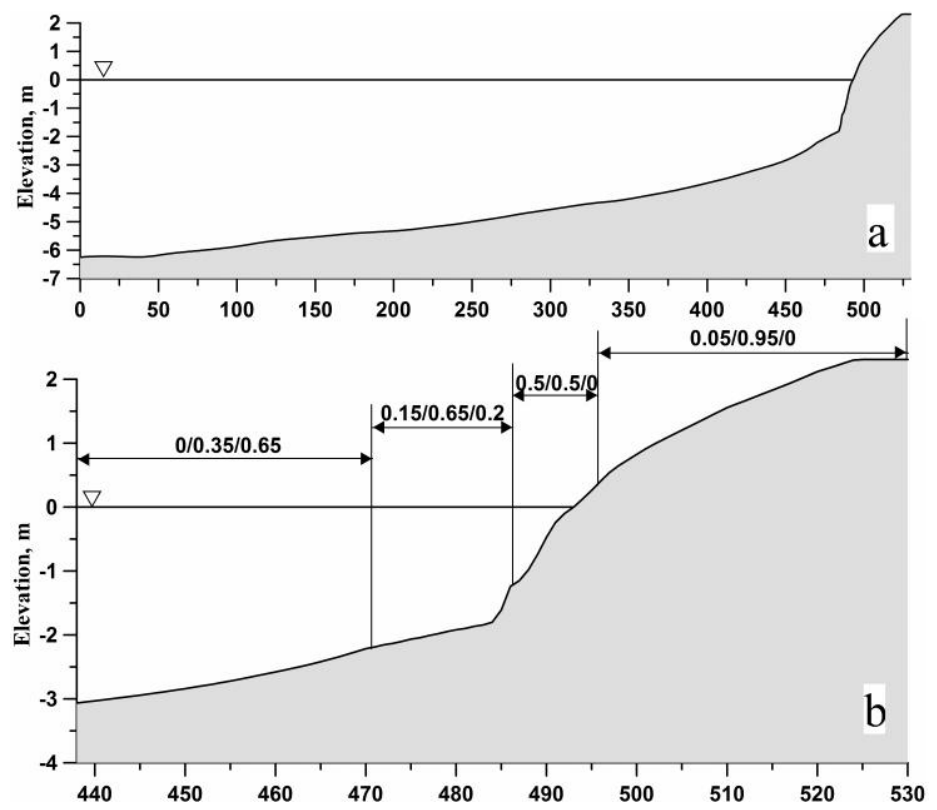

F i g. 1. Profile of the coastal zone $(a)$ and the ratio of volume concentrations of mixture components at the profile sites $(b)$ at the initial time point

The wind wave parameters at the computational domain seaward boundary were predetermined using JONSWAP spectrum: the height of significant waves $H=2 \mathrm{~m}$; the peak period of the waves is $T=6 ; 8$ and $10 \mathrm{~s}$; the parameter of the spectrum peak enhancement was taken equal to 3.3 ; power exponent of the angular dispersion of the waves $l=10$. The rest of the model settings were assumed by default, exception for avalanching parameter [23], for which the following values were used: $d r y s l p=0.1$; wetslp $=0.1$.

The composition of sediments was predetermined in the form of a mixture of three components (fine gravel and coarse sand, medium-grained sand, fine-grained sand). The values of the median diameter $D 50$, as well as $D 15$ and $D 90$ values [23] used as input parameters in the XBeach model, are given in Table 1 . They were obtained by constructing a cumulative curve for each fraction based on the results of granuometric analysis of soil samples *.

* Parmuzina, L.V., 2011. [Granulometric Analysis of Sand-Aleuritic Rocks: Methodologic Instructions for Performing a Laboratory Work on the Discipline "Lithology of Natural Reservoirs of Oil and Gas" for the Specialty 130304 - "Oil and Gas Geology"]. Ukhta: USTU, 23 p (in Russian). 
Granulometric characteristics of the sediments fractions

\begin{tabular}{lcccc}
\hline \multicolumn{1}{c|}{ Fraction } & $D 90, \mathrm{~mm}$ & $D 50, \mathrm{~mm}$ & $D 15, \mathrm{~mm}$ \\
\hline Fine gravel and coarse sand & 1.5 & 0.800 & 0.65 \\
Medium sand & 0.5 & 0.375 & 0.25 \\
Fine sand & 0.2 & 0.150 & 0.10 \\
\hline
\end{tabular}

The amount of a single fraction substance in the mixture is expressed in the volume concentrations corresponding to the shared content of this material in a single volume. At the initial moment of time, the distribution of the ratios of the volume concentrations in different sections of the profile (Fig. 1, b) was predetermined on the basis of the results of field observations and shown down to $3 \mathrm{~m}$ depth, since this input parameter of the model does not change in the seaward part of the profile.

Modeling results and discussion. Under natural conditions, as a result of striving for the formation of quasi-equilibrium profile and optimal distribution of sediment fractions by size, at the given characteristics of the wave effect in the coastal zone rather rapid mutual adjustment of hydrodynamic and lithodynamic processes occurs. The modeling results also showed that the reshaping of the coastal zone profile and the redistribution of sediment fractions start immediately after the onset of wave effect and occur most intensively during the first 3-6 hours. The maximum changes in the values are observed during the first hour of the computational time. In case of applying the model results to real conditions, it should be taken into account that the problem statement presupposes the existence of $2 \mathrm{~m}$ height wave already at the initial time moment. Consequently, the maximum changes in the calculated values obtained after the first hour of wave effect in the model can be interpreted more correctly as occurring at the stage of wave height increase from 0 to $2 \mathrm{~m}$. The duration of this stage can vary.

The modeling results show that in the near-edge strip the profile changes due to the beach erosion with the formation of a rather gentle slope (Fig. 2, a). The material moves to the seaward part of the profile where the accumulative form occurs. During the process of storm wave effect, this form moves towards the sea. Then the position of its seaward boundary stabilizes at a distance of 50-55 $\mathrm{m}$ from the current position of the water edge. This distance characterizes the width of the strip in which large volumes of sand are moved along the normal towards the coast at the predetermined wave parameters and indirectly determines the blocking 
boundary of the alongshore sediment movement during the construction of hydrotechnical structures.
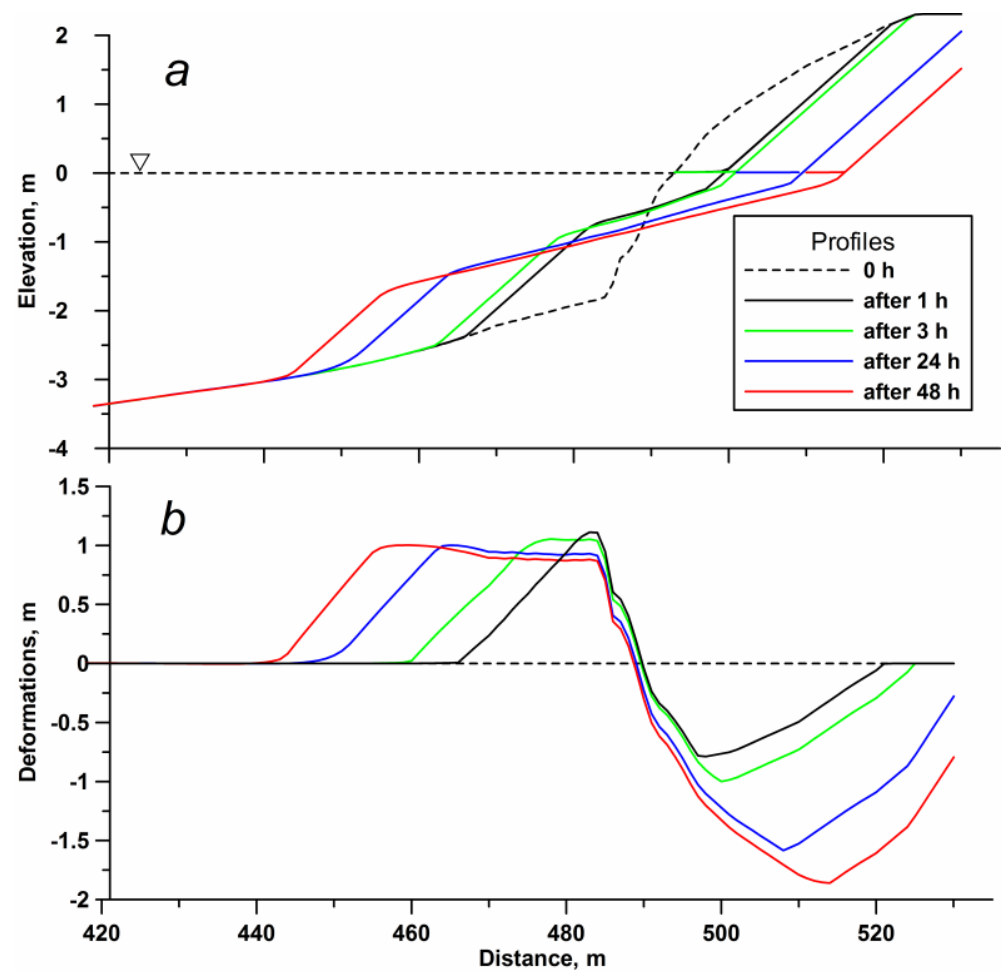

F i g. 2. Change of the coastal zone profile $(a)$ and the value of its deformation (b) at $H=2 \mathrm{~m}$, $T=8 \mathrm{~s}$

In the zone of active profile reprocessing, the smoothing of small-scale relief in homogeneities occurs and three characteristic areas can be distinguished from the slopes of the surface $\beta$. With the change in the period of the waves, the slopes for each section vary insignificantly. The first section $(0.093<\beta<0.102)$ corresponds to the beach surface in the swash zone. Its position is determined by the displacement of the edge line and the width of the processing zone of the beach. The second section $(0.027<\beta<0.040)$ is located on the UCS in the breaking zone of the waves and their most active impact on the bottom surface. Its position is determined by the displacement of the edge line and the seaward boundary of the accumulative body, which is formed as a result of the sediment transport from the coast. The third section $(\beta=0.1)$ is located on the UCS in the seaward part of the accumulative body and has the most stable bottom slopes. Its position is determined by the seaward boundary of the second section and the position of the boundary of the area where the profile wave reprocessing does not occur.

The results of the analysis of the entire calculation series showed that with an increase in the wave period the amount of transported sediment grows, which leads 
to an increase in profile changes. As a result, the re-shaping line of the bottom relief expands, the erosion boundary of the beach shifts towards the coast and the absolute values of deformations increase both in the erosion zone and in the material accumulation zone *. In 24 hours of wave impact at $T=8 \mathrm{~s}$ (Fig. 2, $b$ ), the thickness of the sand erosion layer on the beach can reach $1.5 \mathrm{~m}$, and the decrease in depth in the area of formation of an accumulative body on the UCS is about $1 \mathrm{~m}$.

Water edge retreat rate varies during a storm (Table 2). The highest calculated values are observed after the first hour of model wave impact. Further, as the quasiequilibrium profile is formed, the displacement rate gradually decreases to the values less than $0.2 \mathrm{~m} / \mathrm{h}$. After 48 hours of storm impact, water edge line shifts from $16 \mathrm{~m}$ distance at $T=6 \mathrm{~s}$ to $28 \mathrm{~m}$ at $T=10 \mathrm{~s}$.

Table 2

Rate of the water edge retreat $(\mathrm{m} / \mathrm{h})$

\begin{tabular}{l|c|c|c|c|c|c|c|c|c|c|c|c|c}
\hline \multirow{2}{*}{$T, \mathrm{~s}$} & \multicolumn{11}{c}{ Time of wave effect, $\mathrm{h}$} \\
\cline { 2 - 16 } & 1 & 2 & 3 & 4 & 5 & 6 & 12 & 18 & 24 & 30 & 36 & 42 & 48 \\
\hline 6 & 5.0 & 1.0 & 0.5 & 0.5 & 0.5 & 0.5 & 0.25 & 0.20 & 0.17 & 0.17 & 0.10 & 0 & 0 \\
\hline 8 & 6.0 & 1.0 & 1.0 & 1.0 & 1.0 & 0.5 & 0.50 & 0.33 & 0.25 & 0.20 & 0.20 & 0.20 & 0 \\
\hline 10 & 7.0 & 1.5 & 1.0 & 1.0 & 1.0 & 1.0 & 0.50 & 0.33 & 0.33 & 0.33 & 0.25 & 0.25 & 0.2 \\
\hline
\end{tabular}

An analysis of the beach erosion upper boundary dynamics revealed the fact that the time during which the wave effect reaches the top of the bar is 6 hours at $T=6 \mathrm{~s}, 3$ hours at $T=8 \mathrm{~s}$ and 2 hours at $T=10 \mathrm{~s}$. As a result, when the width of the horizontal part of the bay-bar ridge is $5 \mathrm{~m}$, the waves with $T=6 \mathrm{~s}$ period do not erode it even after 48 hours. At $T=8 \mathrm{~s}$, the deformation of the horizontal part of the bay-bar ridge may begin. At $\mathrm{T}=10 \mathrm{~s}$ the beach erosion line reaches the bay-bar ridge in 2 hours. In 24 hours its erosion and decrease in height by $0.7 \mathrm{~m}$, and after 48 hours - by $1.3 \mathrm{~m}$ are observed.

Variations in the granulometric composition occur as follows. In all numerical experiments the redistribution of larger particles near the shore and, at the same time, the transport of smaller particles into the seaward part is noted.

For coarse material initially concentrated near the edge line, a significant decrease in the volume concentration from 0.5 to 0.1 takes place, and in the zone adjacent to UCS - from 0.15 to 0.1 . One part of the material shifts towards the shore following the retreating edge line, the other is transported toward the sea by a small distance (Fig. 3, a). With an increase in the storm duration, the zone of coarse material distribution expands. With an increase in the wave period the maximum width of its redistribution zone also increases and makes up about $60 \mathrm{~m}$ at $T=6 \mathrm{~s}, 75 \mathrm{~m}$ at $T=8 \mathrm{~s}$ and $85 \mathrm{~m}$ at $T=10 \mathrm{~s}$.

* Gurov, K.I., Fomin,V.V. and Udovik, V.F., 2017. [Modeling of Storm Changes in the Bottom Relief and Granulometric Composition of Bottom Sediments in the Coastal Zone of the Crimean Peninsula]. In: MHI, 2017. Morya Rossii: Nauka, Bezopasnost', Resursy: Tezisy dokladov nauchnoy konferentsii (Sevastopol, 3-7 Oktyabrya 2017) [The Seas of Russia: Science, Safety, Resources: Abstracts of scientific conference papers (Sevastopol, 3-7 October 2017)]. Sevastopol, FSBSI MHI, p. 138 (in Russian). 

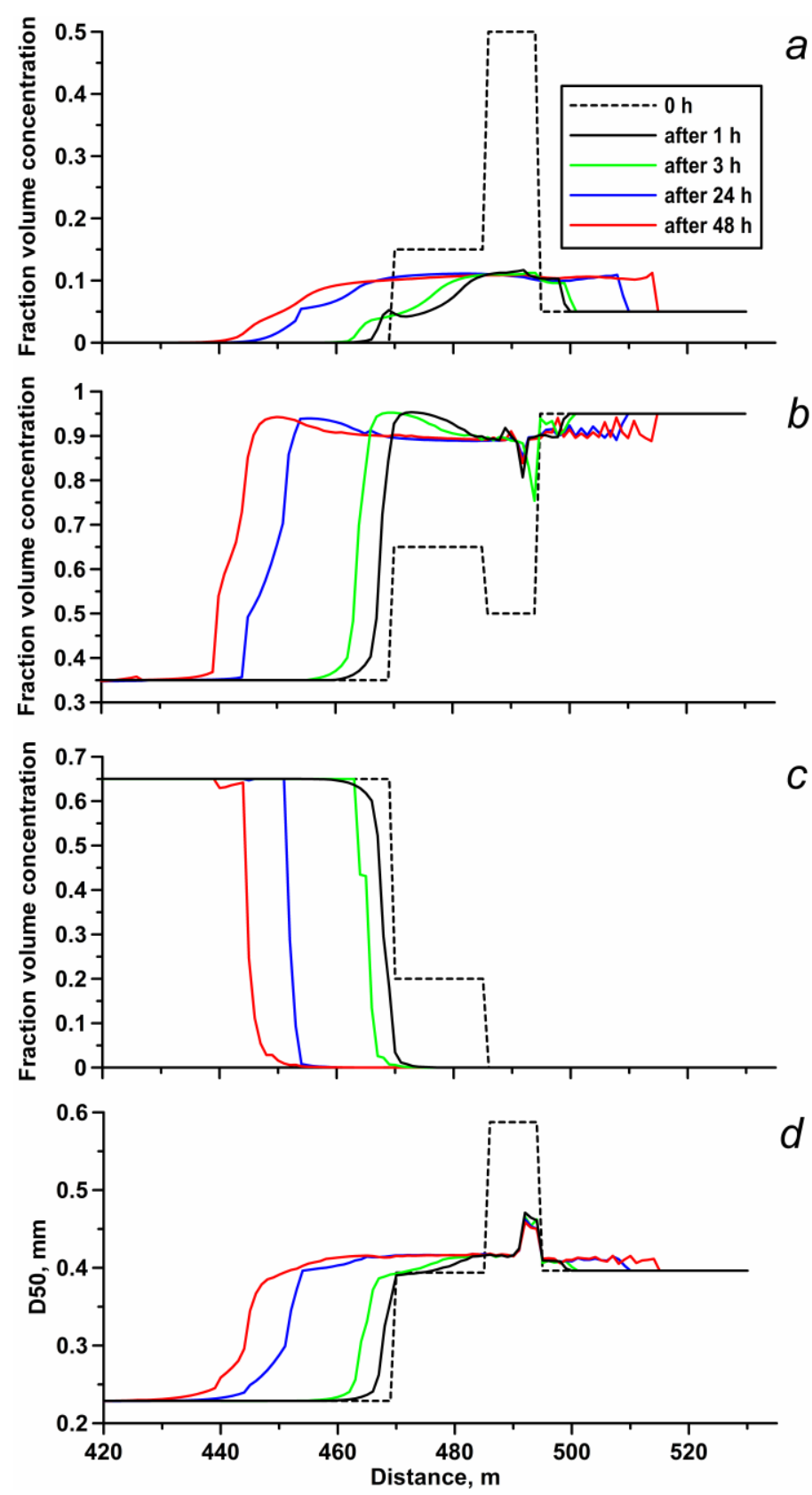

F i g. 3. Variation of volume concentrations of different fractions: the coarse- $(a)$, medium- $(b)$ and fine- $(c)$ grain ones, and that of the median diameter $(D 50)$ calculated for the fraction mixture $(d)$ at $H=2 \mathrm{~m}, T=8 \mathrm{~s}$

The observed increase in the share of medium-grained sand in the mixture (Fig. 3, $b$ ) occurs mainly due to a reduction in the amount of fine-grained fraction (Fig. 3, c). As the duration of the storm increases, the boundary of high concentrations of medium-grained material shifts mainly to the seaward part of the 
profile. After 24 hours of wave effect, the main changes in the volume concentrations of medium-grained material are observed within 40-50-meter line.

Already in the first hours of the storm impact, the fine-grained material is completely transported to the seaward part of the profile, where the volume concentration of this fraction does not change during the entire calculation time (Fig. 3, c). The position of the boundary of fine-grained fraction distribution is shifted towards the sea as the wave period increases.

As a result of transport of single sediment fractions, the distribution of median particle diameter of the entire mixture (D50 parameter, calculated in the XBeach model) varies (Fig. 3, $d$ ). A decrease in its value is observed in the near-edge zone, which is caused by the replacement of coarse-grained material with medium sand. In its turn, in the zone of positive deformations of the bottom profile D50 parameter of mixture growth due to an increase in the share of medium sand and the removal of fine fraction to the profile seaward part. A sharp decrease in the average for the mixture D50 value with a distance from the coast corresponds to the transition zone to the area of extremely fine-grained material accumulation.

\section{Conclusion}

An analysis of numerical modeling results led to the following conclusions.

Deformations of the coastal zone initial profile and the redistribution of all fractions of sediments starts immediately after the onset of the storm effect and the most intensive period is within the first 3-6 hours, depending on the wave period. The main relief changes are noted in the beach zone, where bay-bar erosion is observed, and in the upper UCS part, where the accumulative body is formed. As a result, in the zone of active profile transformation three characteristic areas with different slopes are clearly distinguished. As the wave period increases, the amount of transported material increases due to which the width of the coastal zone relief variation strip and the absolute profile deformations increase. The maximum rates of wave abrasion of the bay-bar seaward slope and the ones of coastline retreat, which are observed at the beginning of the storm, gradually decrease as the quasi-equilibrium profile forms. As the wave period increases, the erosion process intensifies, and this can result in the destruction of the bay-bar ridge and a decrease in its height.

In all numerical experiments an active redistribution of coarser fractions in the upper part of the UCS and unidirectional transport of small particles towards the sea are observed. The main changes in the volume concentrations of single sediment fractions and the median diameter of the mixture particles occur in the near-edge zone of the submarine part of the profile, the coastal boundary of which is determined by the displacement of the water edge line. The accumulative form is formed mainly as a result of medium-grained sand transport during the storm in the upper part of the submarine slope.

\section{REFERENCES}

1. Antsyferov, S.M. and Kosyan, R.D., 1986. Vzveshennye Nanosy v Verkhney Chasti Shel'fa [Suspended Deposits in the Upper Part of the Shelf]. Moscow: Science, 223 p. (in Russian).

2. Leont'yev, I.O., 2008. Budget of Sediments and Forecast of Long-Term Coastal Changes. Oceanology, [e-journal] 48(3), pp. 428-437. https://doi.org/10.1134/ S0001437008030156 
3. Leont'yev, I.O., 2012. Predicting Shoreline Evolution on a Centennial Scale Using the Example of the Vistula (Baltic) Spit. Oceanology, [e-journal] 52(5), pp. 700-709. https:// doi.org/10.1134/S0001437012050104

4. Leont'yev, I.O., Ryabchuk, D.V., Sergeev, A.Yu. and Kovaleva, O.A., 2015. The Forecast of Coastal Recession in the Eastern Gulf of Finland for the Twenty-First Century. Oceanology, [e-journal] 55(3), pp. 434-440. https://doi.org/10.1134/S0001437015030108

5. Kuznetsova, O.A. and Saprykina, Ya.V., 2017. Vnutrigodovye Variacii Shtormovyh Deformacij Rel'efa Dna Peschanogo Poberezh'ja na Primere Kamchijsko-Shkorpilovskogo Pljazha (Chernoe More, Bolgarija) [Intra-Annual Storm Deformations of Sandy Beach by an Example of Kamchia-Shkorpilovtsi Coast (Black Sea, Bulgaria)]. Processes in Geomedia, 1(10), pp. 435-444 (in Russian).

6. Reniers, A.J.H.M., Gallagher, E.L., MacMahan, J.H., Brown, J.A., van Rooijen, A.A., van Thiel de Vries, J.S.M. and van Prooijen, B.C., 2013. Observations and Modeling of SteepBeach Grain-Size Variability. Journal of Geophysical Research: Oceans, [e-journal] 118(2), pp. 577-591. https://doi.org/10.1029/2012JC008073

7. Bugajny, N., Furmańczyk, K., Dudzińska-Nowak, J. and Paplińska-Swerpel, B., 2013. Modelling Morphological Changes of Beach and Dune Induced by Storm on the Southern Baltic Coast Using XBeach (Case Study: Dziwnow Spit). Journal of Coastal Research, [ejournal] 65(sp1), pp. 672-678. https://doi.org/10.2112/SI65-114.1

8. Williams, J.J., Esteves, L.S. and Rochford, L.A., 2015. Modelling Storm Responses on a High-Energy Coastline with XBeach. Modeling Earth Systems and Environment, [e-journal] 1(1-2). Article 3. https://doi.org/10.1007/s40808-015-0003-8

9. Leont'yev, I.O., 2015. O Nekotoryh Svojstvah Processa Formirovanija Shtormovogo Profilja Peschanogo Berega [Some Features of the Process Forming a Storm-Induced Cross-Shore Profile on a Sandy Coast]. Processes in Geomedia, 2, pp. 75-82 (in Russian).

10. Korzinin, D.V., 2015. Osobennosti Formirovanija Profilja Ravnovesija Podvodnogo Beregovogo Sklona (na Primere Akkumuljativnyh Beregov Zapadnogo Kryma) [Features of Formation Equilibrium Profile Underwater Coastal Slope (Accumulative Coast of the West Crimea as Example)]. In: MHI, 2015. Ekologicheskaya Bezopasnost' Pribrezhnoj i Shel'fovoj Zon Morja [Ecological Safety of Coastal and Shelf Zones of the Sea]. Sevastopol: MHI. Iss. 1, pp. 29-33 (in Russian).

11. Gurov, K.I., Fomin, V.V. and Lazorenko, D.I., 2016. Modelirovanie Pereraspredelenija Peschanyh Frakcij po Podvodnomu Beregovomu Sklonu pod Vozdejstviem Vetrovogo Volnenija [Mathematical Modeling of the Redistribution of Sand Fractions According to a Underwater Coastal Slope Under the Influence of the Wind Waves]. In: MHI, 2016. Ekologicheskaya Bezopasnost' Pribrezhnoj i Shel'fovoj Zon Morja [Ecological Safety of Coastal and Shelf Zones of the Sea]. Sevastopol: MHI. 3, pp. 65-71 (in Russian).

12. Fomin, V.V., Gurov, K.I., Udovik, V.F. and Konovalov, S.K., 2019. Dynamics of the Nearshore Zone of Kalamitskiy Gulf (Black Sea) under Influence of Wind Waves. In: EMECS'11 - Sea Coasts, 2019. Materials of XXVI International Coastal Conference "Managing risks to coastal regions and communities in a changing world". Academus Publishing. P. 1-1. https://doi.org/10.31519/conferencearticle_5b1b948b20d587.32401065

13. Zenkovich, V.P., 1958. Morfologija i Dinamika Sovetskih Beregov Chernogo Morja [Morphology and Dynamics of the Soviet Coast of the Black Sea]. Moscow: AN SSSR, 187 p. (in Russian).

14. Mitin, L.I., ed., 2006. Atlas Ohrany Prirody Chernogo i Azovskogo Morej [Atlas of the Black and Azov Seas Conservation]. Saint-Petersburg: GUNiO, 436 p. (in Russian).

15. Goryachkin, Yu.N., ed., 2015. Sovremennoe Sostojanie Beregovoj Zony Kryma [The Current State of the Coastal Zone of Crimea]. Sevastopol: ECOSI-Gidrofizika, 249 p. (in Russian).

16. Shuisky, Yu.D., 2007. Mehanicheskij Sostav Pljazhevyh Nanosov na Zapadnyh Beregah Krymskogo Poluostrova [Mechanical Composition of Beach Drifts on the Western Shores of the Crimea Peninsula]. In: MHI, 2007. Ekologicheskaya Bezopasnost' Pribrezhnoy i Shel'fovoy Zon i Kompleksnoe Ispol'zovanie Resursov Shel'fa [Ecological Safety of Coastal and Shelf Zones and Comprehensive Use of Shelf Resources]. Sevastopol: MHI. Iss. 15, pp. 370-385 (in Russian). 
17. Shuisky, Yu.D., 2005. Osnovnye Zakonomernosti Morfologii i Dinamiki Zapadnogo Berega Krymskogo Poluostrova [The Main Patterns of Morphology and Dynamics of the Western Coast of the Crimean Peninsula]. In: MHI, 2005. Ekologicheskaya Bezopasnost' Pribrezhnoy $i$ Shel'fovoy Zon i Kompleksnoe Ispol'zovanie Resursov Shel'fa [Ecological Safety of Coastal and Shelf Zones and Comprehensive Use of Shelf Resources]. Sevastopol: MHI. Iss. 13, pp. 62-72 (in Russian).

18. Udovik, V.F. and Goryachkin Yu., N., 2013. Mezhgodovaja Izmenchivost' Vdol'beregovogo Potoka Nanosov v Beregovoj Zone Zapadnogo Kryma [Interannual Variability of the Alongshore Sediment Flow in the Coastal Zone of the Western Crimea]. In: MHI, 2013. Ekologicheskaya Bezopasnost' Pribrezhnoy i Shel'fovoy Zon i Kompleksnoe Ispol'zovanie Resursov Shel'fa [Ecological Safety of Coastal and Shelf Zones and Comprehensive Use of Shelf Resources]. Sevastopol: MHI. Iss. 27, pp. 363-368 (in Russian).

19. Udovik, V.F. and Goryachkin, Yu., 2015. Ocenki Mezhgodovoj Izmenchivosti Vdol'beregovogo Transporta Nanosov na Uchastke Beregovoj Zony ot Sevastopolja do Evpatorii [Estimates of Interannual Variability of Alongshore Sediment Transport in the Coastal Zone from Sevastopol to Yevpatoriya]. In: MHI, 2015. Ekologicheskaya Bezopasnost' Pribrezhnoy i Shel'fovoy Zon i Kompleksnoe Ispol'zovanie Resursov Shel'fa [Ecological Safety of Coastal and Shelf Zones and Comprehensive Use of Shelf Resources]. Sevastopol: MHI. Iss. 1, pp. 54-65 (in Russian).

20. Rzheplinsky, G.V., ed., 1969. Atlas Volnenija $i$ Vetra Chernogo Morja [Atlas of the Excitement and Wind of the Black Sea]. Leningrad: Gidrometeoizdat, 111 p. (in Russian).

21. Altman, E.N. and Matushevsky, G.V., eds., 1987. Tipovye Polja Vetra i Volnenija Chernogo Morja [Typical Fields of Wind and Waves of the Black Sea]. Sevastopol: FOL SO GOIN, 116 p. (in Russian).

22. Efimov, V.V. and Komarovskaya, O.I., 2009. Atlas Ekstremal'nogo Vetrovogo Volnenija Chernogo Morja [Atlas of Extreme Wind Waves of the Black Sea]. Sevastopol: ECOSIGidrofizika, 59 p. (in Russian).

23. Roelvink, D., Reniers, A., Van Dongeren, A., van Thiel de Vries, J., Lescinski, J. and McCall, R., 2010. XBeach Model Description and Manual: Report. UNESCO-IHE Institute for Water Education. Deltares, Delft: Deltares and Delft Univ. Technology, 106 p.

About the authors:

Konstantin I. Gurov - Senior Engineer-Researcher, Marine Hydrophysical Institute of RAS (2 Kapitanskaya Str., Sevastopol, 299011, Russian Federation), ORCID ID: 0000-0003- 3460-9650, ResearcherID: L-7895-2017, gurovki@gmail.com

Vladimir V. Fomin - Senior Research Associate, Marine Hydrophysical Institute of RAS (2 Kapitanskaya Str., Sevastopol, 299011, Russian Federation), Dr. Sci. (Phys.-Math.), SPIN-code: 6992-2688, ORCID ID: 0000-0002-9070-4460, ResearcherID: H-8185-2015, v.fomin@ukr.net

Vladimir F. Udovik - Junior Research Associate, Marine Hydrophysical Institute of RAS (2 Kapitanskaya Str., Sevastopol, 299011, Russian Federation), udovik_uvf@mhi-ras.ru

Contribution of the co-authors:

Konstantin I. Gurov - formulation of purposes and objectives of the study, analysis of literature data, analysis and preparation of initial conclusions, processing and description of the research results, qualitative analysis of the results and their interpretation, preparation of the text of the paper

Vladimir F. Udovik - statement and formulation of the problem, qualitative and quantitative analysis of the results, formulation of conclusions, preparation of the text of the paper

Vladimir V. Fomin - correction of the mathematical model and carrying out the calculations, participation in the discussion of the paper materials

All the authors have read and approved the final manuscript.

The authors declare that they have no conflict of interest. 